DOI: $10.19195 / 0137-1134.111 .3$

\title{
AGNIESZKA CHRISIDU-BUDNIK
}

Uniwersytet Wrocławski

\section{ZŁOŚLIWE PROBLEMY W OTOCZENIU ADMINISTRACJI PUBLICZNEJ}

\begin{abstract}
Abstrakt: Artykuł poświęcono zagadnieniu złośliwych problemów — ważnemu w zrozumieniu relacji między administracją publiczną a jej otoczeniem, oraz procedury podejmowania decyzji w rozwiązywaniu tego typu problemów. Dokument opisuje tło złośliwych problemów przedstawione w literaturze przedmiotu. Szczególnie ważna jest identyfikacja potencjalnych przeszkód na drodze do walki ze złośliwymi problemami.
\end{abstract}

Słowa kluczowe: złośliwe problemy, racjonalność, administracja publiczna, rozwiązanie

\section{WPROWADZENIE}

Otoczenie administracji publicznej stanowi złożony, dynamiczny układ, który tworzą różne oddziaływające na siebie elementy. Owe elementy powiązane są zależnościami funkcjonalnymi i tworzą strukturę, z którą administracja wchodzi w bezpośrednie lub pośrednie relacje. Administracja publiczna jest istotnym elementem owej struktury, a relacje między nią a otoczeniem mają charakter dwustronny.

Otoczenie wpływa na administrację: podejmowane decyzje, strukturę organizacyjną, wewnętrzne procesy organizacji pracy, perspektywy oznaczające, w jaki sposób postrzega, konstruuje rzeczywistość, oraz na jej modele myślenia ${ }^{1}$. Otoczenie zatem implikuje procesy przystosowawcze do zmian w nim zachodzących².

${ }^{1}$ Praktycznym odzwierciedleniem owych modeli myślenia jest na przykład wykształcenie się paradygmatów New Public Management, New Public Governance.

2 Wpływ otoczenia na administracje publiczną uwzględnili autorzy koncepcji krytycznych wobec Weberowskiego typu idealnego biurokracji. Wspomniane alternatywne koncepcje wykraczały poza ramy teoretyczne stworzone przez Maxa Webera, istotne było przede wszystkim uwzględnienie otoczenia jako jednej ze zmiennych niezależnych, determinujących na przykład strukturę organizacji. Nie sposób tu wymienić wszystkich alternatywnych koncepcji, a nawet uwydatnić różnic między nimi, dlatego ograniczam się do wskazania koncepcji relatywistycznej teorii organizacji P.R. Lawrence'a i J.W. Lorscha. Autorzy przyjęli wiele hipotez wstępnych, z których wymienię jed- 
Jednocześnie aktywność administracji wywołuje zmiany w jej otoczeniu. Franciszek Longchamps podkreślał, iż „zjawisko administracyjne, będąc działaniem kulturowym, wprowadza zmiany w rzeczywistości"3. Działalność administracji polega na: ustalaniu priorytetów (co najpierw robić), doborze metod i środków w celu realizacji zamierzeń, podejmowaniu decyzji, komu powierzyć realizację ustalonych zadań. Podejmowanie decyzji w każdym wymienionym obszarze, w niekończącym się szeregu spraw, które administracja prowadzi, wyznacza obszar polityki administracyjnej ${ }^{4}$. Dla prowadzonych tu rozważań istotne jest podkreślenie, że polityka administracyjna to suwerenny obszar pytań i rozstrzygnięć, których wynikiem są działania, a ich celem inicjowanie zmian w otoczeniu. Odwołanie się do pojęcia „układ administracyjny” cja jako element struktury „działa” na inne jego elementy, gdy zmianom w danym elemencie towarzyszą lub następują po nich zmiany w innych elementach. Istotna jest interakcja — zmiany w tych innych elementach są w jakimś stopniu zależne od zmian w danym elemencie - to znaczy są one spowodowane przez tamte zmiany. W tym sensie termin „działanie” może okazać się nieadekwatny, w istocie mamy do czynienia z oddziaływaniem — układu administracyjnego na otoczenie i otoczenia na układ administracyjny.

Proces obopólnego oddziaływania należy rozpatrywać w kontekście sytuacyjnym. Do końca XIX wieku, kiedy ówczesne funkcjonowanie państwa było relatywnie proste, uważano, że administracja to działalność państwa, której celem jest utrzymanie porządku wewnętrznego, zapewnienie dochodów, podstawowych usług komunalnych, wspieranie szkolnictwa, wymiaru sprawiedliwości, utrzymywanie stosunków międzynarodowych. Realizacja celów ówczesnej administracji wymagała relatywnie małego współdziałania wyspecjalizowanych funkcji. Dlatego też Weberowski typ idealny biurokracji idealizował racjonalność organizacji biurokratycznej. Tymczasem wzrost złożoności środowiska administracji, między innymi w wyniku wielkich przemian społecznych, postawił racjonalność organizacji typu biurokratycznego pod znakiem zapytania, a jednocześnie spowodował wzrost złożoności celów i zadań administracji publicznej. Już w okresie po pierwszej wojnie światowej działalność administracji publicznej objęła politykę socjalną, agrarną, dokonała się rozbudowa administracji ubezpieczeniowej itp. Otoczenie administracji publicznej stanowią te czynniki zewnętrzne, które wpływają na realizację jej celów organizacyjnych. Im bardziej złożone jest środowisko, tym większa niepewność -

ną. Podstawową zmienną charakteryzującą otoczenie jest stopień jego pewności, który odzwierciedlają trzy wskaźniki: szybkość (tempo) zmian w otoczeniu, jakość uzyskiwanej informacji o zmianach zachodzących w otoczeniu organizacji i upływ czasu między działaniem a dotarciem informacji zwrotnej o efekcie działania; zob. P.R. Lawrence, J.W. Lorsch. Organization and Environment, Boston, MA 1967.

${ }^{3}$ F. Longchamps, Założenia nauki administracji, Wrocław 1991, s. 92.

${ }^{4}$ Por. J. Starościak, Administracja. Zagadnienia teorii i praktyki, Warszawa 1974, s. 139.

${ }^{5}$ F. Longchamps, op. cit., s. 89 n. 
tym mniej przewidywalne są skutki podejmowanych przez administrację działań oraz tym większe skomplikowanie jej struktury. Jeżeli administracja funkcjonuje w coraz bardziej złożonym środowisku i chce wykorzystać swój potencjał, to owa złożoność otoczenia musi znaleźć swoje odzwierciedlenie w złożoności jej celów i zadań, a to z kolei warunkuje typ przyjętej struktury ${ }^{6}$. Integracja wzrostu złożoności otoczenia i struktur administracji publicznej stała się szczególnie widoczna w okresie po drugiej wojnie światowej. Spowodowane to było „wzrostem interwencji państwa w sektor prywatny i ogólnym wzrostem sektora publicznego (administracji). [...] szczególnie w krajach wyniszczonych wojną, potrzebna była wielka interwencja państwa, aby odbudować zniszczone infrastruktury i społeczeństwo"?. Formą interwencji był etatyzm, tworzenie nowych instytucji publicznych, rozwój usług publicznych, pogłębione procesy decentralizacji władzy, instytucjonalizacja sektora organizacji non profit. Z perspektywy samego układu administracyjnego widoczne się stało, że jego cele są pochodną funkcji, które układ realizuje na rzecz otoczenia. Dostrzeżono także procesy segmentacji otoczenia, to znaczy wielowymiarowy proces rozczłonkowania otoczenia, jego podziału na wiele względnie autonomicznych wycinków. Adaptacja administracji publicznej do rzeczywistości zaczęła przybierać postać pluralistyczną; różne segmenty otoczenia oddziałują na administrację publiczną, która z kolei modyfikuje swoją strukturę organizacyjną, metody i techniki działania i w tym sensie jako taka stanowi nieodłączny element struktury społecznej. Zjawiska i procesy powstające bądź to w otoczeniu administracji, bądź inicjowane przez samą administrację determinują jej stan oraz rzutują na kształtowanie jej otoczenia.

\section{WICKED PROBLEMS W PERSPEKTYWIE RADYKALNYCH INNOWACJI}

Pod koniec lat 60. XX wieku, zwłaszcza w obszarze polityki planowania przestrzennego, ujawnił się nowy typ problemów, które między innymi cechowały: wysoki stopień komplikacji, trudność w ich rozwiązaniu, ograniczenia w obiektywnej ocenie przyjętych rozwiązań. Próba denotacji powyższych problemów podjęta została przez Herberta Simona, który stworzył koncepcję problemów źle strukturalizowanych (ill-structured problems) ${ }^{8}$. Russell Ackoff posługiwał się z kolei określeniem „dzikie problemy” (messy problems $)^{9}$. W odniesieniu do pla-

${ }^{6}$ Por. A.Z. Kamiński, Władza a racjonalność. Studium z socjologii wspótczesnego kapitalizmu, Warszawa 1976, s. 15.

${ }^{7}$ A.J. Dębicka, Sprawne państwo, Warszawa 2008, s. 28.

${ }^{8}$ H.A. Simon, Does scientific discover have a logic?, „Philosophy of Science” 1973, nr 40 (3-4), s. 471-480.

${ }^{9}$ R. Ackoff, The future of operational research in past, „The Journal of the Operational Research Society" 1979, nr 30 (2), s. 93-104. 
nowania miejskiego na początku lat 70. XX wieku urbaniści Horst Rittel i Melvin Webber użyli terminu ,złośliwe problemy” (wicked problems $)^{10}$.

$\mathrm{Z}$ uwagi na ograniczone ramy artykułu nie jest możliwe dokonanie systematycznej analizy trzech wymienionych rodzajów problemów. Istotne jest podkreślenie, że już w latach 70. dostrzeżono, że mogą one generować tzw. koszt niepewności i koszt nieracjonalności, odnosząc to pierwsze pojęcie do braku informacji, a drugie — do nieodpowiedniego ich użycia. Obecnie w literaturze przedmiotu zwłaszcza dwie kategorie — messy problems i wicked problems — są utożsamiane ${ }^{11}$.

$\mathrm{W}$ drugiej połowie XX wieku tempo i jakość zmian społeczno-gospodarczo-kulturowych uruchomiły proces krytyki administracji publicznej, która dotyczyła nieskutecznego rozwiązywania przez nią problemów w sferze oświaty, zarządzania przestrzenią miejską, niekontrolowanego przyrostu ludności, dysproporcji rozwojowych, niedostępności do opieki medycznej ${ }^{12}$. W kolejnych dekadach wyzwaniem dla administracji publicznej stała się adaptacja do otoczenia zmienianego przez globalne ocieplenie. Poszukiwanie przez administrację, często w formie partnerstwa publiczno-prywatnego, rozwiązań mających zwiększyć efektywność energetyczną i doprowadzić do redukcji gazów cieplarnianych jest przykładem zapobiegania skutkom zmian klimatycznych.

Nie sposób tu wymienić wszystkie problemy, z jakimi styka się współczesna administracja i które determinują zmianę jej stanu. Wydaje się, że jedno zjawisko wywiera niezwykle istotny wpływ na charakter zmian, które zachodzą w otoczeniu administracji publicznej i w konsekwencji, w długiej perspektywie czasu, modyfikują zasady jej funkcjonowania. Zjawisko to określane jest mianem radykalnych, zakłócających innowacji (disruptive innovations). Terminu disruptive innovations użył po raz pierwszy Clayton Christensen, który w sposób pogłębiony wyjaśnia jego genezę, charakter i skutki ${ }^{13}$. Radykalnymi innowacjami są technologie, produkty lub usługi, których przełomowy potencjał powoduje, iż zmieniają

${ }^{10}$ H.W.J. Rittel, M.M.Webber, Dilemmas in a general theory of planning, „Policy Sciences” 1973, nr 4 (2), s. 155-169.

11 Zob. S. Ney, Resolving Messy Policy Problems, Earthscan 2009, s. 6 n.

${ }^{12}$ Wymienione problemy, powstałe wskutek procesów industrializacji, w istocie nie były nowym zjawiskiem. Czynnikiem uruchamiającym gwałtowny wzrost w XIX wieku migracji ludności z obszarów wiejskich do Nowego Jorku, Chicago, Berlina, Londynu była rewolucja przemysłowa. Zagęszczenie, złe warunki sanitarne i pracy, zanieczyszczenie środowiska związane z rozwojem przemysłu sprawiły pogorszenie stanu zdrowia oraz skrócenie średniej długości życia populacji miejskiej. Konieczność adaptacji ówczesnej administracji publicznej do nowych problemów w jej otoczeniu spowodowała, iż zwłaszcza administracja samorządowa skoncentrowała się na ochronie zdrowia ludności miejskiej, inwestując w poprawę jakości wody i warunków sanitarnych, usuwanie odpadów komunalnych, edukację. Zob. G. McGranahan, D. Satterthwaite, Urban centers: an assessment of sustainability, „Annual Review of Environment and Resources” 2003, nr 28, s. 243-274.

${ }^{13}$ C.M. Christensen, M.W. Johnson, D.K. Rigby, Foundations for growth: How to identify and build disruptive new businesses, „MIT Sloan Management Review” 2002, nr 43 (3), s. 22-31; C.M. Christensen, S.D. Anthony, E.A. Roth, Seeing What's Next: Using the Theories of Innovation to Predict Industry Change, Boston 2004. 
one zasady funkcjonowania struktury społeczno-gospodarczo-instytucjonalnej $\mathrm{z}$ administracją jako jej elementem. Przegląd literatury przedmiotu pozwala dostrzec, iż uwaga poszczególnych autorów jest skupiona przede wszystkim na rynkowych aspektach radykalnych innowacji, na ich wpływie na osiąganie przewagi konkurencyjnej, konkretny sektor i gospodarkę ${ }^{14}$. Pomija się w zasadzie wpływ omawianych innowacji na funkcjonowanie administracji publicznej, jej aksjologię, wewnętrzną organizację, relacje $\mathrm{z}$ otoczeniem — a nawet — powstawanie teoretycznych wzorców jej funkcjonowania.

Radykalne innowacje nie pojawiły się w XXI wieku, na przykład wynalezienie maszyny parowej stało się katalizatorem rewolucji przemysłowej, industrializacji, które między innymi doprowadziły do silnego ukształtowania się racjonalno-instrumentalnej orientacji w działalności przedsiębiorstw i administracji. Racjonalno-instrumentalna orientacja znalazła swój wyraz w socjologicznej refleksji Maxa Webera oraz w refleksji organizatorskiej Fredericka Taylora. Jednocześnie rewolucja przemysłowa uruchomiła $\mathrm{w}$ otoczeniu administracji wiele procesów o złożonym charakterze, które z dzisiejszej perspektywy można określić mianem wicked problems. Omawiane problemy wpływały na to, że administracja publiczna zmieniała w czasie swoje funkcje, zadania, metody działania.

Niewątpliwie przykładem współczesnej disruptive innovation było wykorzystanie w nowych obszarach istniejącej od ponad dwudziestu lat technologii, jaką jest Internet, który doprowadził do informatyzacji administracji (e-administracja) ${ }^{15}$. Powstawanie nowych technologii doprowadziło do rozwoju społeczeństwa informacyjnego, w którego obrębie zmieniły się sposoby budowania relacji międzyludzkich, instytucjonalnych, w tym relacji urząd-obywatel, a także oczekiwania obywateli wobec urzędu ${ }^{16}$. Jednocześnie zakłócające innowacje prowadzą do powstania nowych usług, które nie tylko przekształcają gospodarkę i odzwierciedlają przemiany społeczno-kulturowe, lecz także trudno jednoznacznie określić ich charakter prawny. Przykładem jest korporacja Uber, której działanie opiera się na modelu biznesowym określanym mianem ekonomii współdziałania (sharing economy). Przedmiot działalności wskazanej korporacji budzi kontrowersje (na przykład podatki) i oczekiwania kierowane wobec administracji publicznej o jej wykluczenie z rynku.

${ }^{14}$ A.A. King, B. Baatartogtokh, How useful is the theory of disruptive innovations, „MIT Sloan Management Review” 2015, nr 57 (1), s. 77-90; C. Markides, Disruptive innovations in need of better theory, „Product Innovation Management” 2006, nr 26, s. 19-25; A. Chrisidu-Budnik, A. Sus, Contemporary strategic innovations in the Indian medical industry - a descriptive approach to problem, „Wroclaw Review of Law, Administration \& Economics” 2014, nr 4 (2), s. 26-40.

${ }^{15} \mathrm{~W}$ kontekście informatyzacji administracji publicznej (e-administracja) w literaturze przedmiotu zwraca się uwagę na negatywne skutki wykorzystywania narzędzi elektronicznej w pracy urzędników; zob. M. Kulesza, D. Sześciło, Polityka administracyjna i zarzadzanie publiczne, Warszawa 2013, s. 55.

${ }^{16}$ Nowe technologie zapoczątkowały i ułatwiły implementację nowych modeli świadczenia usług publicznych; zob. D. Sześciło, Wspótzarządzanie jako kooprodukcja usług publicznych, „Zarządzanie Publiczne” 2015, nr 1 (31), s. 13-21. 
Korporacja stworzyła segment pracy dorywczej w ramach istniejącego sektora usług przewozowych; próby wejścia na rynek hiszpański zakończyły się zawieszeniem działalności Ubera w tym państwie. Sąd w Barcelonie zwrócił się do Trybunału Sprawiedliwości UE z wnioskiem o wydanie orzeczenia w przedmiocie kwalifikacji prawnej usług świadczonych przez korporację. Trybunał Sprawiedliwości podejmie decyzję, czy Uber świadczy usługi transportowe, pośrednictwa elektronicznego, czy też usługę społeczeństwa informacyjnego (sprawa C-434/15, w toku przed TSUE). Rozstrzygnięcie w przedmiocie charakteru usług Ubera będzie miało długofalowe konsekwencje dla korporacji (działalności lokalnych spółek w poszczególnych państwach UE), co nie stanowi przedmiotu zainteresowania w kontekście przyjętego celu artykułu. Uznanie przez Trybunał Sprawiedliwości UE za usługę transportową, społeczeństwa informacyjnego, czy też społeczeństwa informacyjnego wyznaczą działania administracji. Jak już wspomniano, układ administracyjny musi przystosowywać się do zmieniających się sytuacji zachodzących w jego otoczeniu; procesy adaptacji mogą być modyfikowane przez prawo. Największe problemy adaptacji stwarzają jednak wicked problems, które z racji na swoją złożoność, zasięg oddziaływania, niejednoznaczność i nieprzewidywalność wpływu tworzą szczególne wyzwania dla administracji publicznej.

\section{ATRYBUTY WICKED PROBLEMS}

Termin wicked problems ma takie znaczenie, jakie nadali mu Horst Rittel i Melvin Webber w 1973 roku, kiedy analizowali problematykę planowania rozwiązań społecznych w obszarze konkretnych polityk publicznych ${ }^{17}$. Nie podejmując się jednoznacznego zdefiniowania tego terminu, a rozpoznając i poddając refleksji elementy konstytuujące omawiane zjawisko, zidentyfikowali dziesięć zasadniczych jego atrybutów.

Problem definicji (sformułowania). Trudność w precyzyjnym zdefiniowaniu problemu wynika z braku możliwości jednoznacznej identyfikacji jego źródeł, a także jego złożoności i dynamiki. Rozpatrywany problem może ewoluować, zmieniać się i przybierać coraz to nowe formy. Aktywność administracji publicznej niejako od początku osadzona jest w otoczeniu społeczno-kulturowym, które determinuje proces definiowania przez nią problemów. Definicja problemu obejmuje trzy podstawowe wymiary. Po pierwsze, doświadczenie lokalizowane w czasie i przestrzeni ${ }^{18}$. Odnosi się nie tylko do teraźniejszości, lecz także przeszłych i antycypowanych zdarzeń. Po drugie, kontekst i relacje. Każdy złośliwy problem osadzony jest w określonym kontekście, znaczy coś jako element tego kontekstu i jednocześnie jako element relacji uwarunkowanych przez normy, wartości,

\footnotetext{
${ }^{17}$ Ibidem.

${ }^{18}$ F. Longchamps używa określenia „wydarzenia przestrzenno-czasowe”; zob. idem, op. cit., s. 93.
} 
tradycje dominujące $\mathrm{w}$ danym państwie lub strukturach ponadnarodowych. Po trzecie, administracja publiczna może nadawać tym samym problemom odmienne sensy czy znaczenia, to znaczy przypisywać im odmienne wartości. Problemy, o których mowa, administracja publiczna postrzega przez pryzmat różnych punktów odniesienia, sposobów interpretacji rzeczywistości. Każdy problem, który administracja jest zmuszona rozwiązać, wymaga prawidłowego sformułowania, to znaczy jego zlokalizowania w kontekście czasowo-przestrzennym wraz z określeniem jego rozmiaru, wewnętrznej struktury oraz konsekwencji dla otoczenia. Problem definicji problemu polega na jego konkretyzacji od strony meritum i treści. Istotne jest precyzyjne rozpoznanie jego przyczyn oraz właściwa prezentacja formalna. Sformułowanie problemu dotyczy więc jego treści i formy. Praktycznym odzwierciedleniem zasygnalizowanych elementów tworzących problem definicji jest przykład globalnego ocieplenia. Ujawnia się tu różnica stanowisk i perspektyw, z jakimi administracja publiczna oraz społeczność międzynarodowa patrzy na ten sam problem. Odmienne perspektywy są konsekwencją różnic kulturowo-historycznych, rozwojowych, aktualnej struktury gospodarki, lobbingu, stosunku do innowacji społecznych. Różnice są tak znaczne, iż niektóre administracje negują lub podważają istnienie samego problemu globalnego ocieplenia.

Problem wyników. Trudność w wyznaczeniu punktu, w którym dany problem można uznać za definitywnie rozwiązany. W praktyce funkcjonowania administracji publicznej implikacje występowania problemu wyników są przynajmniej dwojakie. Po pierwsze, przyjęcie określonego rozwiązania i zaprzestanie zajmowania się problemem oznacza akceptację zadowalającego rozwiązania. Postawie takiej towarzyszy świadomość odroczenia w czasie wystąpienia symptomów i skutków częściowo rozwiązanego problemu. Po drugie, trudność w wyznaczeniu wspomnianego punktu komplikuje proces ustalenia skuteczności rozwiązania problemu. Skuteczność stanowi podstawową postać sprawnego działania. Miarą skuteczności jest skutek zamierzony przyjęty jako cel; stopień zbliżenia się do przyjętego celu przez podmiot działający uzasadnia wyodrębnienie działań: skutecznych, nieskutecznych i przeciwskutecznych ${ }^{19}$. Dylematy związane z wyznaczeniem punktu docelowego, który administracja publiczna przyjmuje jako azymut definitywnego rozwiązania konkretnego problemu, skutkują brakiem precyzji w wyznaczeniu celu lub celów jej działania. Istnienie wicked problems uświadamia, że działania administracji publicznej nie wyczerpują się w świadomym, racjonalnym i zaplanowanym postępowaniu zamierzającym do osiągnięcia celu. Działania administracji w obszarze rozwiązywania omawianych problemów niejednokrotnie są wynikiem kumulatywnych, a nie zaplanowanych, przystosowawczych reakcji na wydarzenia i procesy zachodzące w jej otoczeniu. Współwystępowanie zaplanowanego i kumulatywnego stosunku administracji do procesów zachodzących w jej otoczeniu jest szczególnie widoczne

19 Zob. J. Korczak, Sprawność działania jako podstawowe kryterium oceny działania, [w:] A. Chrisidu-Budnik et al., Nauka organizacji i zarzadzania, Wrocław 2005, s. 154-155. 
w podejściu do problemu kryzysu migracyjnego. Wynikiem zaplanowanego postępowania jest rozporządzenie Parlamentu Europejskiego i Rady (UE) nr 604/2013 z 26 czerwca 2013 roku w sprawie ustanowienia kryteriów i mechanizmów ustalania państwa członkowskiego odpowiedzialnego za rozpatrzenie wniosku o udzielenie ochrony międzynarodowej złożonego w jednym z państw członkowskich przez obywatela państwa trzeciego lub bezpaństwowca. Wyrazem działań kumulatywnych, które jednocześnie stanowią zadowalające - często oparte na kompromisie - rozwiązanie problemu, jest podpisanie w 18 marca 2016 roku między Unią Europejską a Republiką Turcji umowy zatytułowanej Oświadczenie UE-Turcja (18 marca 2016 roku). Zgodnie z porozumieniem każdy nielegalny przybysz, który trafi na jedną z greckich wysp (Samos, Kos, Leros, Lesbos, Chios) lub zostanie podjęty na morzu, po szybkiej weryfikacji może zostać odesłany do Turcji, jeżeli nie wykaże i udowodni, że przysługuje mu prawo do azylu. W zamian za każdego odesłanego imigranta, który nielegalnie przedostał się na greckie wyspy, Unia Europejska ma przyjąć jednego syryjskiego uchodźcę bezpośrednio z tureckiego obozu. Regulacje te tymczasowo blokują możliwość kontynuacji podróży na kontynent, ale rozwiązują problem migracji i tym samym można im przypisać walor czasowej, ograniczonej skuteczności.

Problem kryteriów. Według Rittela i Wbbera często nie można dokonać jednoznacznej oceny rozwiązania konkretnego problemu w kategoriach ,prawidłowe” lub „błędne”, zasadna jest ocena rozwiązania w kategoriach „lepsze” lub „gorsze". Nie istnieją bowiem obiektywne, precyzyjne kryteria oceny rozwiązania. Formułowanie kryteriów łączy się z procesem wartościowania - nadawania im określonych preferencji — kształtowanych pod wpływem złożonych czynników, jak wiedza, aksjologia, potrzeby społeczne, prawdopodobieństwo. Sposób wartościowania kryteriów oceny rozwiązania problemu wpływa na prawidłowość decyzji ostatecznej. Im bardziej problem jest skomplikowany i trudny, tym wyższe prawdopodobieństwo, że przyjęte kryteria oceny jego rozwiązań nie doprowadzą do skutku przyjętego za cel działania. W kontekście problemu kryteriów należy wspomnieć, że administracja publiczna coraz częściej jest zmuszona przyjmować tzw. regresywną metodę ekonomizacji działań. Metodę regresywną stosuje się, gdy akceptuje się jednoczesny spadek wyniku użytecznego działania oraz cenności kosztów działania, z tym że koszty działania muszą maleć szybciej niż jego wynik użyteczny ${ }^{20}$. W naukach o zarządzaniu przyjmowano, że metody regresyjnej administracja używa przede wszystkim w sytuacjach wyjątkowych (stan klęski żywiołowej, wojna). Obecnie metoda regresywna — zwłaszcza w warunkach kryzysu ekonomicznego - stała się sposobem reakcji na rozwiązywanie problemów niewypłacalnych lub zadłużonych państw strefy euro. Akceptacja regresywnej metody ekonomizacji działań przez administrację publiczną jest wynikiem

${ }^{20}$ Zob. J. Korczak, op. cit., s. 160. 
wartościowania kryteriów, co oznacza, że administracja publiczna musi dążyć do otrzymania rozwiązania zadowalającego, a nie optymalnego.

Problem konsekwencji (skutków). Nie istnieje możliwość weryfikacji wypracowanego rozwiązania problemu, jego implementacja wywołuje także nieprzewidywane i wielorakie konsekwencje - ekonomiczne, polityczne, społeczne. Omawiany problem dostrzegł Herbert Simon. Istotnym elementem wypracowanego przez Simona modelu ograniczonej racjonalności jest bowiem niemożność przewidzenia wystąpienia wszystkich konsekwencji określonej decyzji. Aby podmiot działający zachowywał się całkowicie racjonalnie, musiałby dysponować pełnym opisem konsekwencji wynikających z każdej alternatywnej strategii i musiałby te konsekwencje z sobą porównywać. Musiałby precyzyjnie wiedzieć, jak otaczająca go rzeczywistość zareaguje na jego takie, a nie inne zachowania ${ }^{21}$.

Deficyt wiedzy o wszystkich konsekwencjach decyzji, której przedmiotem jest rozwiązanie problemu, powiększa się tym szybciej, im bardziej złożony, skomplikowany jest problem. Zwłaszcza w odniesieniu do wicked problem administracja publiczna w praktyce posługuje się nie informacjami ,pełnymi”, ale tylko dostępnymi, które pozwalają częściowo antycypować skutki przyjętego w drodze decyzji rozwiązania problemu. W 2002 roku samorząd w Melbourne, w reakcji na spadek opadów atmosferycznych, wprowadził restrykcyjne normy konsumpcji wody. Po kilku latach pojawił się nieprzewidywany skutek takiego rozwiązania w postaci szybszej korozji rur kanalizacyjnych, którymi płynie wprawdzie mniej ścieków, ale za to gęstszych i mających wyższą temperaturę ${ }^{22}$.

Problem nieodwracalności. Każde rozwiązanie jest jednorazową operacją. Administracja publiczna może uczyć się na błędach, to znaczy: a) zdawać sobie sprawę z popełnionych błędów; b) rozumieć i wyciągać wnioski; c) uwzględniać popełnione błędy w przyszłych procesach decyzyjnych, ale nie jest w stanie odwrócić zaistniałej sytuacji będącej wynikiem przyjętego przez nią sposobu rozwiązania problemu. Rozwiązanie każdego wicked problem jest jednorazową sytuacją w tym sensie, że tworzy nowe uwarunkowania, które determinują decyzje podejmowane w późniejszym okresie.

Problem nieograniczoności. Nie istnieje zamknięta liczba wyczerpujących rozwiązań. Administracja publiczna podchodzi do otoczenia, w którym funkcjonuje i na które wpływa, z ograniczonym i charakterystycznym zestawem reakcji. Reakcja oznacza tu sposób, w jaki administracja odnosi się do swojego otoczenia, schemat postępowania wobec problemów, a także pewnego rodzaju standard, który obejmuje obowiązujące $\mathrm{w}$ danym kontekście interpretacje problemów. Istotne jest to, iż wspomniany standard może ograniczać perspektywę poznawczą oraz działania administracji i tym samym blokować poszukiwanie nowych — zwłasz-

${ }^{21}$ H.S. Simon, Działanie administracji, Warszawa 1976, s. 165.

${ }^{22}$ C. Rosenzweig et al., Climate Change and Cities: First Assessment Report of the Urban Climate Change, Cambridge 2011, s. 113 n. 
cza niestandardowych — rozwiązań problemów. Od interpretacji problemu przyjętej przez administrację publiczną zależy na przykład tempo adaptacji do zmian klimatycznych i redukcja jej kosztów. Sposób reakcji na omawiany problem może znaleźć swoje odzwierciedlenie w procesach poszukiwania, finansowania i wdrażania innowacyjnych rozwiązań dotyczących redukcji emisji dwutlenku węgla, oszczędzania wody, ochrony miejskiej sieci transportowej. Uzasadnione wydaje się tu przypomnienie rozważań Longchampsa nad pytaniem „w jakim stopniu prawo wyznacza administrację [...]"23. Niezwykle aktualne jest „twierdzenie o zasadzie legalności, jako czymś towarzyszącym stale administracji [...”224.

Problem niepowtarzalności. Każdy wicked problem jest jedyny w swoim rodzaju — osadzony jest w konkretnym kontekście, do jego rozwiązania potrzebne są odmienne zasoby materialne i niematerialne. Konieczne jest zatem uczenie się w ramach administracji publicznej, które winno być co najmniej równe wielkości i tempu przemian środowiskowych. Istotnym wyzwaniem, któremu powinna sprostać administracja, jest przejście od deskryptywnego traktowania rzeczywistości do jej sprawnego kształtowania - podejście preskryptywne ${ }^{25}$. Jego przejawem jest proces planowania. Istotą planu, co odróżnia go między innymi od prognoz, jest realizacja zawartych w nim ustaleń. Implementacja planowania wymaga ciągłego wyboru priorytetów społecznych i środków do realizacji. Rittel i Webber proces planowania traktowali jako przedmiot konstruktywnego sporu, w którego trakcie wykształca się ogląd problemu (rozpoznanie) oraz propozycje jego rozwiązania ${ }^{26}$. We współczesnej literaturze przedmiotu zauważa się, że planowanie polityk publicznych jest osadzone w sieci. „W wyspecjalizowanych funkcjonalnie sieciach dokonuje się nie tylko wymiana informacji i danych na potrzeby konstruowania i implementacji polityk publicznych, lecz przede wszystkim wytwarza się wiedzę, promuje innowacyjne rozwiązania"27. Tworzenie sieci jest: a) wynikiem zmiany funkcji państwa; b) dyfuzji władzy, która przekazywana jest „,do góry”, „do dołu” oraz w wyniku procesów kontraktualizacji ,na zewnątrz" 28 ; c) przejawem wzrostu zależności w procesach stanowienia polityk publicznych ${ }^{29}$.

${ }^{23}$ F. Longchamps, op. cit., s. 165.

24 Ibidem.

${ }^{25}$ E.W.K. Tsang, Organizational learning and the learning organization: A dichotomy between descriptive and perspective research, „Human Relations” 1997, $\mathrm{nr} 50$ (1), s. 84-85.

${ }^{26}$ H.W.J. Rittel, M.M. Webber, op. cit., s. 162.

27 S. Mazur, K. Olejniczak, Rola organizacyjnego uczenia się we współczesnym zarządzaniu publicznym, [w:] Organizacje uczace się. Model dla administracji publicznej, red. K. Olejniczak, Warszawa 2012, s. 39-40.

${ }^{28}$ Zob. na przykład A. Modrzejewski, Kontraktualizacja w globalnym i europejskim prawie administracyjnym, [w:] Wypieranie prawa administracyjnego przez prawo cywilne, red. A. Doliwa, S. Prutis, Warszawa 2012, s. 219-238.

${ }^{29}$ Zob. na przykład V.T. Hocking, V.A. Brown, J.A. Harris, Tackling wicked problems through collective design, „Intelligent Buildings International” 2016, nr 8 (1), s. 24-36. 
Problem odzwierciedlenia. Każdy wicked problem może być symptomem innego problemu. Administracja publiczna musi projektować rozwiązania, wiedząc, iż nie rozwiązuje rzeczywistych przyczyn problemu, a jedynie niweluje jego skutki. Wskazać też można na sytuacje, w których administracja nie jest w stanie zidentyfikować rzeczywistych przyczyn problemu, które stają się zrozumiałe dopiero po upływie dłuższego okresu. Gwałtowna urbanizacja, która rozpoczęła się w XIX wieku (Londyn powiększył się siedmiokrotnie, a Nowy Jork aż sześćdziesięciokrotnie) była skutkiem rewolucji przemysłowej. Wcześni intelektualiści nie potrafili zidentyfikować przyczyny zjawiska urbanizacji, dostrzegali symptomy — miasta były przeludnionymi skupiskami ubóstwa, przestępczości, chorób. Wspomniana w artykule korporacja Uber jest emanacją zakłócających innowacji, której usługi nie tylko podważają logikę funkcjonowania dotychczasowych rynków, implikują pytania o ich charakter prawny, lecz także odzwierciedlają inne problemy: „dorywczej” pracy (elastyczność czasu pracy), migracji (kierowcy w krajach Unii Europejskiej i Ameryce Północnej są w przeważającej mierze migrantami), paradoksu oczekiwań społeczności, którzy z jednej strony — jako obywatele - formułują coraz wyższe oczekiwania wobec państwa, a z drugiej strony — jako konsumenci — oczekują i chcą korzystać z „nieopodatkowanych” i „niesformalizowanych” usług.

Problem luki. Złośliwe problemy tworzą lukę to znaczy rozbieżność między stanem rzeczywistym a pożądanym. Podmioty zaangażowane w proces antycypowania pożądanego stanu mogą przyjmować różne perspektywy, czyli punkty widzenia określające sposób, w jaki percypują otaczającą ich rzeczywistość. Problem luki staje się szczególnie widoczny, gdy konkretny wicked problem ma charakter ponadnarodowy lub globalny, a administracje poszczególnych krajów przyjmują odmienne perspektywy. Owe perspektywy, czyli punkty widzenia, między innymi tworzą: założenia, wartości, normy i idee, które oddziałują na percepcję administracji i wpływają na to, jakiego rodzaju politykę publiczną preferuje administracja publiczna. Jeżeli wicked problem ma charakter globalny, decydującego znaczenia nabierają wspomniane perspektywy oraz mechanizmy wypracowywania i uzgadniania wspólnych stanowisk, współdziałania i koordynacji.

Problem błędu. Administracja publiczna jako podmiot odpowiedzialny za stworzenie planu rozwiązania problemów społecznych nie powinna się mylić. Poruszony problem błędu ma — ogólnie rzecz biorąc — dwa aspekty. Pierwszy z nich dotyczy problemu realizacji odpowiedzialności administracji publicznej, która przyjmuje postać relacji trójczłonowej: zachodzi między administracją a społeczeństwem i dotyczy określonego problemu społecznego. Podmioty gospodarcze rozważają konsekwencje swoich decyzji, które tylko ich dotyczą, podczas gdy administracja publiczna musi analizować konsekwencje swoich wyborów w kontekście ich wpływu na różne sfery funkcjonowania społeczeństwa ${ }^{30}$. Drugi

${ }^{30}$ Por. H. Simon, op. cit., s. 166. 
jest efektem tego, że administracja publiczna, rozpoznając obiektywne uwarunkowania rozwiązania omawianych problemów i definiując to, co jest interesem publicznym, tworzy ład społeczny. Relacja między administracją publiczną a otoczeniem de facto dokonuje się w dwóch procesach — strukturyzacji rzeczywistości i formalizacji rzeczywistości. Obecnie Internet, będący atrybutem funkcjonowania administracji publicznej i obywateli, stał się strukturalnym elementem rzeczywistości, dokonując głębokich przeobrażeń w sposobach wykonywania pracy, pozyskiwania informacji, dostępu do dóbr i usług publicznych oraz prywatnych itp. Jednocześnie ciągle ujawniają się i nowe możliwości, i zagrożenia, które wiążą się z korzystaniem z Internetu. Celem formalizacji jest zapewnienie maksymalizacji korzyści tych pierwszych, a ograniczenie lub eliminacja negatywnych tych ostatnich.

\section{KONTINUUM ZŁOŚLIWYCH PROBLEMÓW}

Podjęta przez Rittela i Webbera analiza zjawiska wicked problem zapoczątkowała na gruncie krytyki ich artykułu procesy poszukiwania i dążenia do stworzenia obrazu „czystej” struktury omawianych problemów. Podnoszono argumenty, że wyodrębnienie przez autorów dziesięciu atrybutów konstytuujących omawiane zjawisko nie pozwala na jego precyzyjną i jednoznaczną identyfikację. Podkreślano także, że akceptacja przyjętej przez Rittela i Webbera optyki badawczej uzasadnia twierdzenie, że większość problemów będących przedmiotem polityk publicznych ma strukturę złośliwych problemów. Wynikiem krytyki była dystynkcja między złośliwymi i oswojonymi problemami (tame problems). Nie chodziło o dokonanie dychotomicznego podziału na te dwie kategorie, ale o konstrukcje kontinuum „złośliwości”, na którego jednym końcu będą znajdować się „czyste” oswojone problemy, na drugim zaś „czyste” złośliwie problemy ${ }^{31}$.

„czyste”

oswojone problemy
„Czyste"

złośliwe problemy

Rys.1. Kontinuum złośliwych problemów

Źródło: opracowanie własne.

Uważam, że konstrukcja owego kontinuum pozwala nie tylko na ukazanie opozycji problemy oswojone-problemy złośliwe, ale dostrzeżenie, że istnieją róż-

${ }^{11}$ Zob. R.A. Heifetz, Leadership without Easy Answers, Cambridge, Mass. 1994; B.W. Head, J. Alford, Wicked problems: implications for public policy and management, „Administration \& Society" 2015, $\mathrm{nr} 47$ (6), s. 711-739. 
ne stopnie złośliwości problemów (degrees of wickedness ) ${ }^{32}$. Przegląd literatury uświadamia, iż wskazuje się na różne podstawowe różnice między złośliwymi i oswojonymi problemami. W dalszej części artykułu przedstawiam — moim zdaniem — najistotniejsze różnice, które pozwalają ustalić dystynkcje między nimi.

Problemy istniejące w otoczeniu administracji w różnym stopniu destabilizują funkcjonowanie struktury społecznej. Stopień destabilizacji jest pochodną tego, czy wyłonił się on wskutek zaistnienia znanej, możliwej do zidentyfikowania i określenia przyczyny, czy też ma on charakter losowy. Istotna jest zatem dystynkcja między determinizmem a probabilizmem. Oswojone problemy mają charakter deterministyczny, administracja publiczna zna źródła powstania problemu oraz rozumie reguły (zasady), na podstawie których się rozwija. Determinizm jako cecha oswojonych problemów oznacza zatem, że ma on wyznaczoną trajektorię, według której działa i rozwija się w czasie. Znajomość trajektorii umożliwia administracji wywieranie wpływu na przebieg i skutki problemu w czasie i przestrzeni. Probabilizm jako cecha złośliwych problemów oznacza, że administracja publiczna nie zna rzeczywistych źródeł ich powstania, lecz jedynie z określonym stopniem prawdopodobieństwa wnioskuje o jego przyczynach. Probabilistyczny charakter skutkuje brakiem możliwości kompleksowej analizy problemu, to znaczy polega na przypisaniu jego powstaniu zazwyczaj jednego określonego czynnika i potraktowaniu go jako fundamentu sformułowania problemu. W rezultacie przyjęcie rozwiązania konkretnego wicked problem jest ograniczone, to znaczy jednostronne, nie odzwierciedla całej złożoności problemu, prowadząc do podejmowania w swojej strukturze decyzji zadowalających.

Administracja publiczna dokonuje procesów modelowania rzeczywistości, proces ten jest wynikiem złożoności otoczenia i problemów, które w nim występują. Modelowanie złośliwych problemów obciążone jest przynajmniej trzema błędami. Pierwszy, który określam mianem intencjonalności, polega na wnoszeniu do opisu i rozwiązania problemu aksjologicznego i emocjonalnego stosunku. Wpływ aksjologii i emocji na percepcje problemu utrudnia, a w skrajnych przypadkach uniemożliwia obiektywizm. Aksjologia i emocje konstytuują kryteria, które wpływają na sądy i wybory dokonywane w procesach rozwiązywania złośliwych problemów. Drugi polega na upolitycznieniu problemu, który znajduje wyraz w samym jego postrzeganiu i formułowaniu preferowanych wyników ${ }^{33}$.

${ }^{32}$ Stopień złośliwości problemów wprowadza konkretyzację omawianego zjawiska, ukazując jego względność i zmienność. W literaturze wyodrębnia się kategorię problemów wyjątkowo złośliwych, zalicza się do nich te, których rozwiązanie poddane jest szczególnej presji czasu, na przykład zmiany klimatu. Zob. R.J. Lazarus, Super wicked problems and climate change: restraining the present to liberate the future, „Cornell Law Review” 2009, nr 94 (5), s. 1153-1234.

${ }^{33}$ Zwłaszcza upolitycznienie procesu ustalania pożądanych wyników, które ma przynieść rozwiązanie określonego problemu, nie pozwala sformułować jego prawidłowego rozwiązania. W tym kontekście zwraca się uwagę, że tym, co diametralnie różni organizacje sektora publicznego od organizacji sektora prywatnego, jest w tym pierwszym - a zwłaszcza w administracji publicznej — brak precyzyjnych mierników, czym jest niepowodzenie polityki (policy failure), a czym 
Trzeci - poznawczy — polega na niemożności uchwycenia istotnych, ale często ukrytych współzależności między elementami problemu, które jednak powinny znaleźć odwzorowanie w modelowaniu rzeczywistości.

\section{ZAKOŃCZENIE}

Wzrastająca złożoność otoczenia, znajdująca odwzorowanie w dynamice zmian, nieprzewidywalności oraz tzw. turbulencyjności, zmusza administrację publiczną do rozwiązywania niezdefiniowanych problemów o dużym stopniu wzajemnych powiązań, tzw. złośliwych problemów. Dynamika i charakter problemów wywierają mocny wpływ na racjonalność i przebieg procesów decyzyjnych mających doprowadzić do rozwiązania problemów. Administracja publiczna musi rozwiązywać decyzje w warunkach niepewności, co łączy się z dużym ryzykiem oraz nieprzewidywalnością konsekwencji implementowanych rozwiązań. Administracja publiczna jest przykładem systemu złożonego. Aby móc adaptować się do zmieniających się warunków w otoczeniu, a jednocześnie racjonalnie i efektywnie kształtować rzeczywistość, administracja publiczna winna dążyć do poznania wewnętrznej struktury i dynamiki złośliwych problemów oraz wdrożyć myślenie lateralne, które cechuje elastyczność i kreatywność.

\section{WICKED PROBLEMS IN ENVIRONMENT OF PUBLIC ADMINISTRATION}

Summary

The paper deals with the issue of wicked problems — the important concept to understand relationship between public administration and it's environment and decision making structure in resolving such type of problems. The paper provides some background on the wicked problems literature. Particularly important here, is identification a potential barriers to tackling wicked policy problems.

Keywords: wicked problems, rationality, public administration, solution

powodzenie polityki (policy success), a ponadto przypisywanie owym miernikom różnych wartości. Zob. A. McConell, What is policy failure? A primer to help navigate the maze, „Public Policy and Administration" 2015, nr 30 (3-4), s. 221-242; B.G. Peters, State failure, governance failure and policy failure: exploring the linkages, „Public Policy and Administration” 2015, nr 30 (3-4), s. 261-276. 


\section{BIBLIOGRAFIA}

Ackoff R., The future of operational research in past, „The Journal of the Operational Research Society" 1979, $\mathrm{nr} 30$ (2).

Chrisidu-Budnik A., Sus A., Contemporary strategic innovations in the Indian medical industry a descriptive approach to problem, „Wroclaw Review of Law, Administration \& Economics” 2014, $\mathrm{nr} 4$ (2).

Christensen C.M., Anthony S.D., Roth E.A., Seeing What's Next: Using the Theories of Innovation to Predict Industry Change, Boston 2004.

Christensen C.M., Johnson M.W., Rigby D.K., Foundations for growth: how to identify and build disruptive new businesses, „MIT Sloan Management Review”2002, nr 43 (3).

Dębicka A.J., Sprawne państwo, Warszawa 2008.

Doliwa A., Prutis S., Wypieranie prawa administracyjnego przez prawo cywilne, Warszawa 2012.

Head B.W., Alford J., Wicked problems: implications for public policy and management, „Administration \& Society" 2015, nr 47 (6).

Heifetz R.A., Leadership without Easy Answers, Cambridge, Mass. 1994.

Hocking V.T., Brown V.A., Harris J.A., Tackling wicked problems through collective design, „Intelligent Buildings International" 2016, nr 8 (1).

Kamiński A.Z., Władza a racjonalność. Studium z socjologii wspótczesnego kapitalizmu, Warszawa 1976.

King A.A., Baatartogtokh B., How useful is the theory of disruptive innovations, „MIT Sloan Management Review" 2015, 57 (1).

Korczak J., Sprawność działania jako podstawowe kryterium oceny działania, [w:] A. Chrisidu-Budnik, J. Korczak, A. Pakuła, J. Supernat, Nauka organizacji i zarzadzania, Wrocław 2005.

Kulesza M., Sześciło D., Polityka administracyjna i zarzadzanie publiczne, Warszawa 2013.

Lawrence P.R., Lorsch J.W., Organization and Environment, Boston, Mass. 1967.

Lazarus R.J., Super wicked problems and climate change: restraining the present to liberate the future, „Cornell Law Review” 2009, nr 94 (5).

Longchamps F., Założenia nauki administracji, Wrocław 1991.

Markides C., Disruptive innovation: in need of better theory, „,The Journal of Product Innovation Management" 2006, nr 26.

McConell A., What is policy failure? A primer to help navigate the maze, „Public Policy and Administration" 2015, nr 30 (3-4).

McGranahan G., Satterthwaite D., Urban centers: an assessment of sustainability, „Annual Review of Environment and Resources" 2003, nr 28.

Migranci, migracje, red. H. Thiollet, Kraków 2017.

Ney S., Resolving Messy Policy Problems, Earthscan 2009.

Organizacje uczace się. Model dla administracji publicznej, red. K. Olejniczak, Warszawa 2012.

Peters B.G., State failure, governance failure and policy failure: exploring the linkages, „Public Policy and Administration" 2015, nr 30 (3-4).

Rittel H.W.J., Webber M.M., Dilemmas in a general theory of planning, „Policy Sciences” 1973, nr 4 (2).

Rosenzweig C., Solecki W.D. Hammer S.A., Mehrotra S., Climate Change and Cities First Assessment Report of the Urban Climate Change Research Network, Cambridge 2011.

Simon H.A., Does scientific discover have a logic?, „Philosophy of Science” 1973, nr 40 (3-4).

Simon H.A., Działanie administracji, Warszawa 1976.

Starościak J., Administracja. Zagadnienia teorii i praktyki, Warszawa 1974.

Sześciło D., Współzarządzanie jako kooprodukcja usług publicznych, „Zarządzanie Publiczne” 2015, nr 1 (31).

Tsang E.W.K., Organizational learning and the learning organization: A dichotomy between descriptive and perspective research, „Human Relations” 1997, nr 50 (1). 